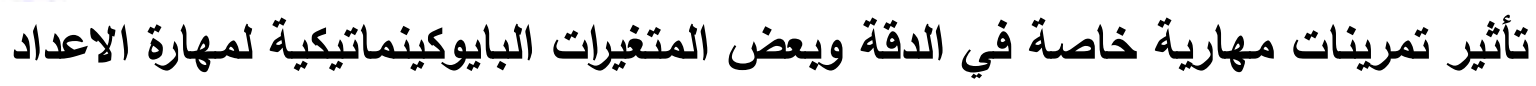

الواطئ والعالي من القفز للاعبين المعدين الشباب في اندية بغداد للكرة الطائرة

عمار وليد عباس (1)، علاء محسن ياسر (2)

تأريخ تقديم البحث: (2021/6/29)، تأريخ قبول النشر (2021/7/27)، تأريخ النشر (2021/9/28) DOI: https://doi.org/10.37359/10.37359/JOPE.V33(3)2021.1187

\begin{abstract}
المستخلص
هدفت الدراسة الى التعرف على تأثنر بعض التمرينات المهارية الخاصة في بعض المتغيرات الكينماتيكية ودقة مهارة

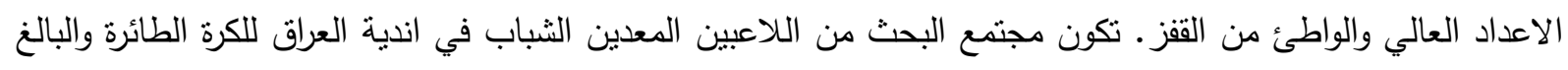

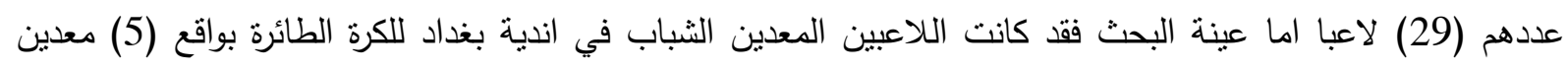

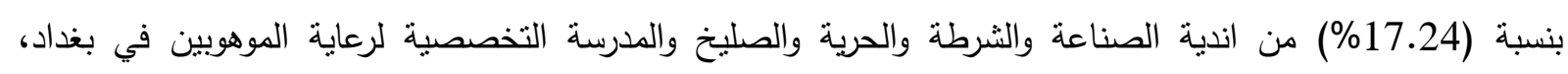

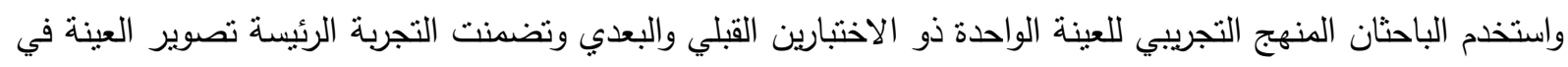
اثثاء الاختبارات بكاميرا ذات قدرة تصويرية (240 صاث) لغرض استخراج المتغيرات البايوكينماتيكية، ثم طبق الباحثان التمرينات المهارية الخاصة لمدة شهرين وبعدها تمت التجربة البعدية بظروف التجربة القبلية نفسها تبع ذلك تحلئ التيل النتائج

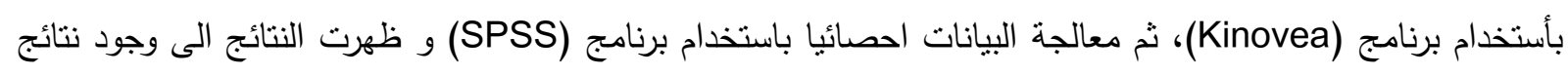

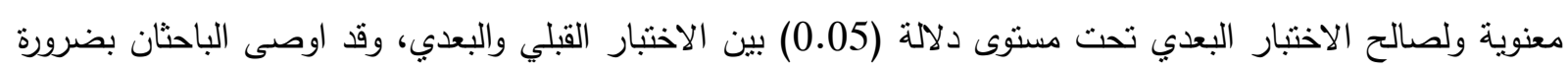

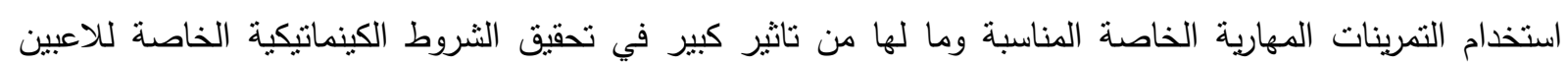
المعدين والتي من شأنها نطوير المسارات الحركية وبالتالي تحقيق افضل اعداد ممكن.

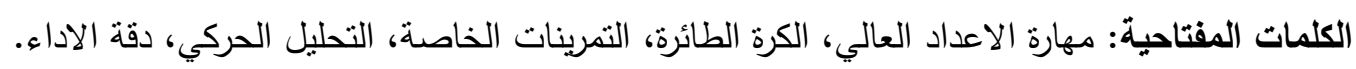

\title{
ABSTRACT \\ The Effect of Special Skill exercises on Accuracy and Some Bio - kinematical Variables in Low and High Setting for Youth Setters Baghdad Volleyball Clubs
}

The study aimed at identifying the effect of some special skill exercises on some biokinematical variables and the accuracy of low and high jump setting in volleyball. The subjects were (29) youth setters from Baghdad clubs only (5) setters were selected from Al Senaa, Al Shorta, Al Huria, Al Selaik, and the specialized schools for gifted in Baghdad. The researchers used the experimental method and the main experiment included taping the subject with (240 pix/se) camera to extract bio- kinematical variables. The special skill exercises were applied for two months followed by posttests. The data was analyzed using (Kinovea) then statistically using SPSS. The results showed significance in favor of posttests. Finally the recommended the necessity of using special skill exercises due to their great effect on setting kinematics that develops the motor pathways of setting.

Keywords: high setting, volleyball, special exercises, motor analyses, performance accuracy.

(1) طالب دراسات عليا (الماجستير) ، جامعة بغد/د، كلية التربية البدنية وعلوم الرياضة. (Ammarwaleed03@gmial.com) Ammar Waleed Abbas, Post graduate student (Master), University of Baghdad, College of physical education and sport sciences, (Ammarwaleed03@gmial.com)(009647711837671).

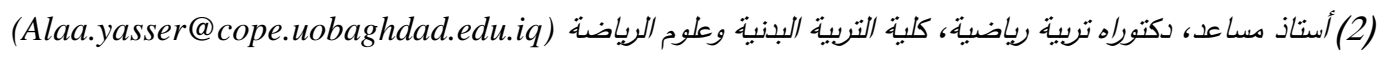
Alaa Mohsin Yasser, Assistant Prof (PHD), University of Baghdad, College of physical education and sport sciences, (Alaa.yasser@cope.uobaghdad.edu.iq)(009647707992708) 


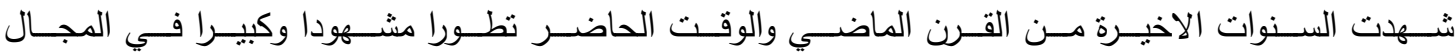

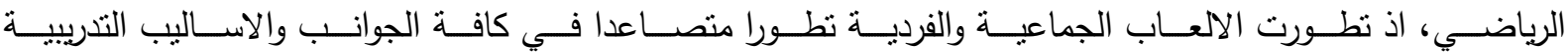

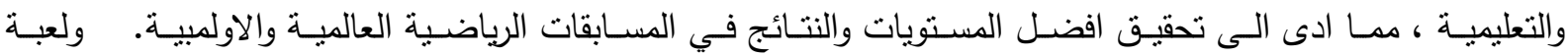
الكرة الطـائرة واحدة مـن الألعـاب الجماعيـة التـي شـهـت تطورا كبيـرا ومنسـارعا في السـنوات ، والتطور الذي حدث

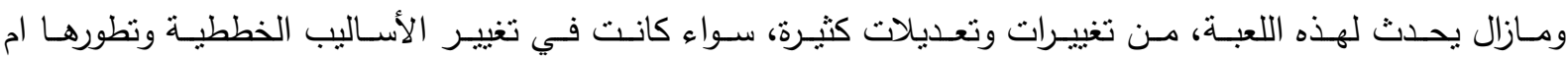

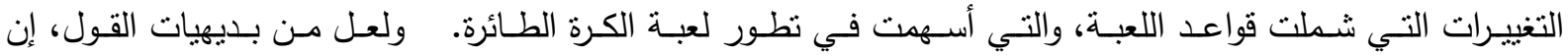

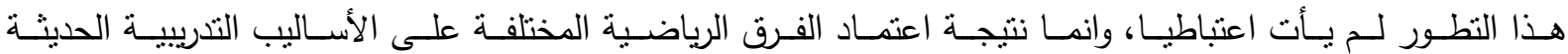

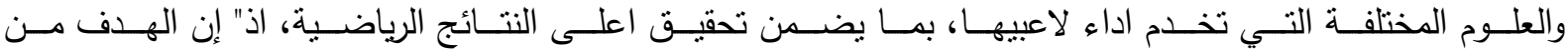

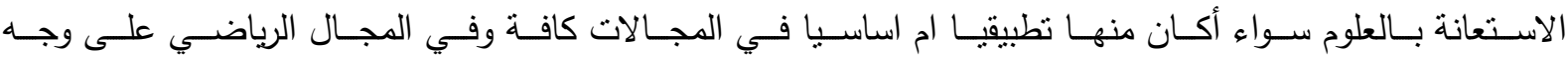
الخصوص هو الطريق الوحيد للارتقاء بمستوى لاداءومن ثم النهوض بالانجاز • (محمود، 1999) .

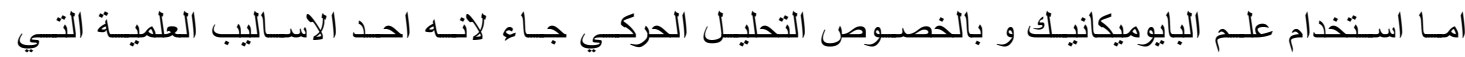

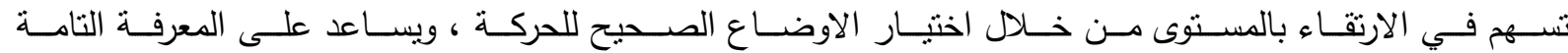

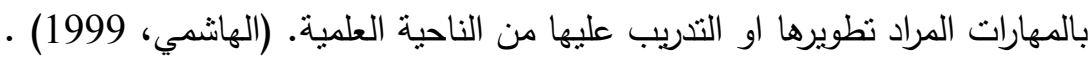

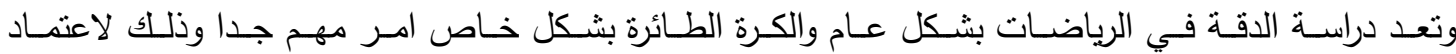

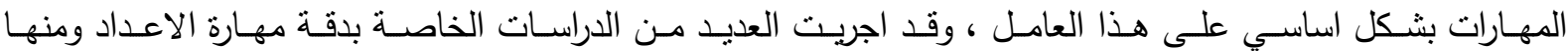

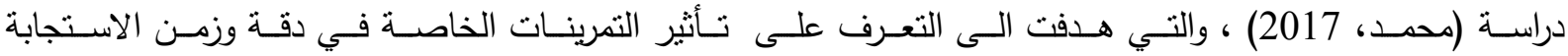

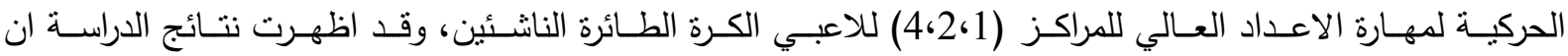

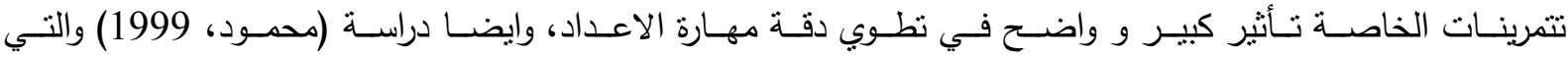
هدفت السى التعرف على تأثير جهاز مقترح لتطوير السـوك الحركي و مدى تـأثيره على الدقـة مهارات لعبـة الكرة

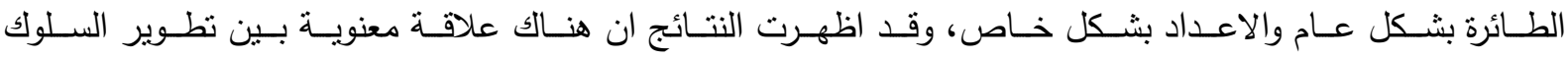

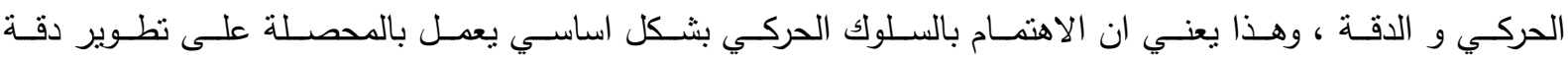
المهارة .

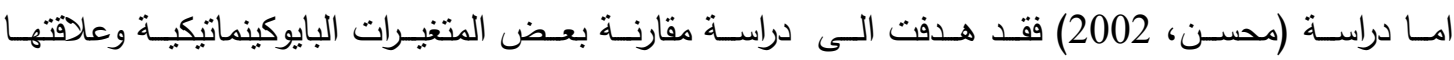

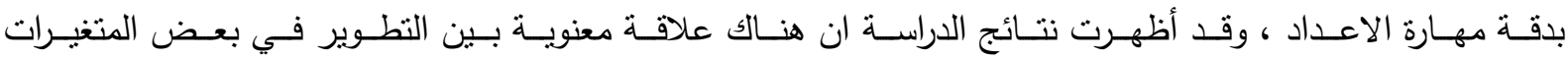

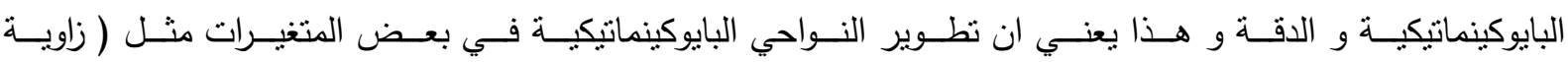

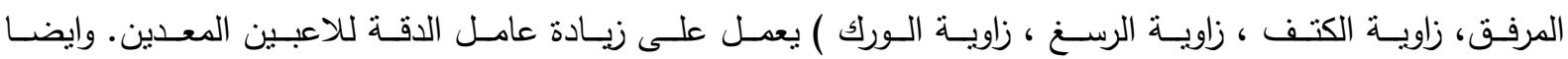

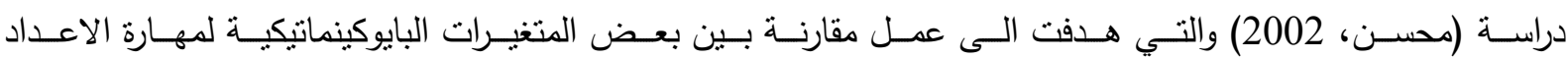

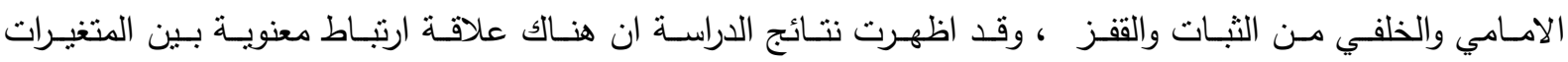

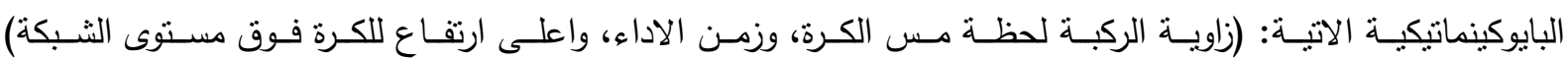

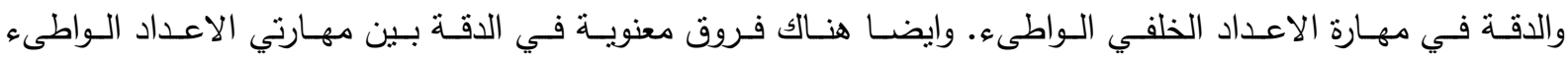

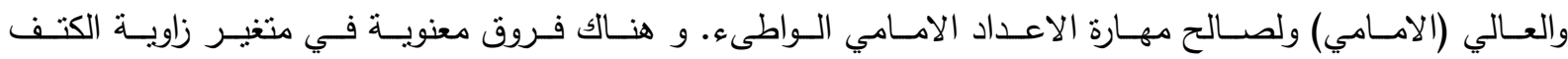

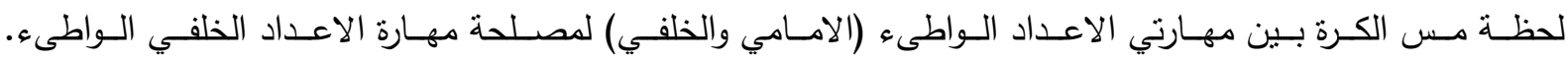

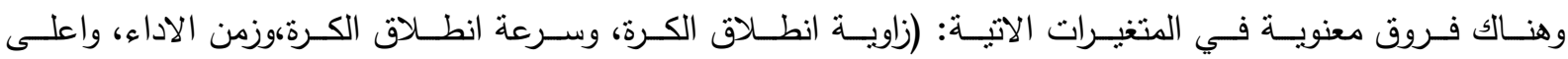

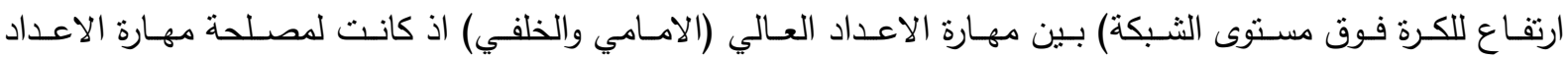

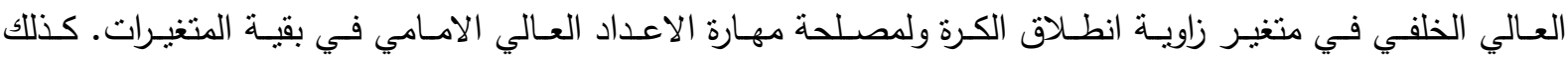




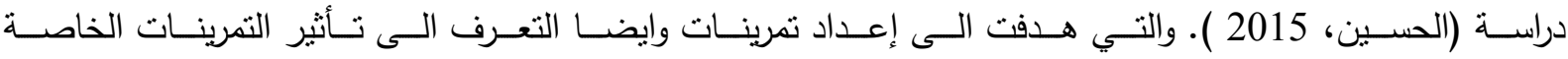

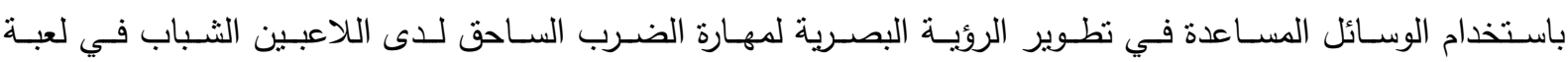

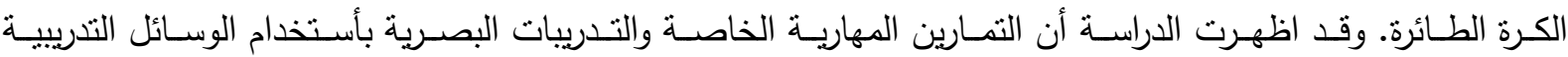
المسـاعدة أتثرت أيجابيـاً فـي تطـوير مهـارة الضـرب الســاحق فـي المراكـز (4-3-2) للمجموعـة التجريبيـة وأظهـرت

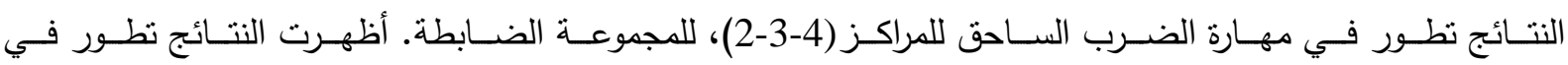
الروية البصرية والدقة لمهارة الضرب الساحق للمراكز (4-3-2)، للمجموعة الضابطة.

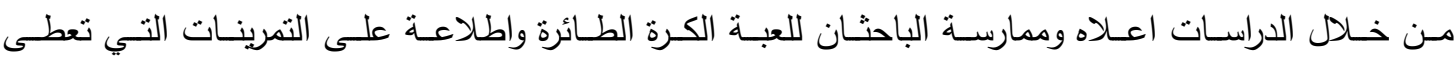

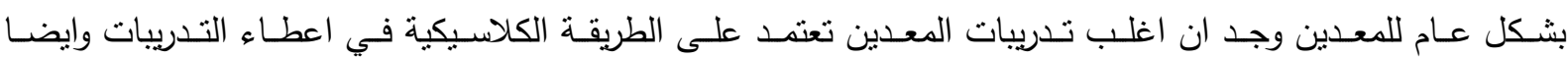

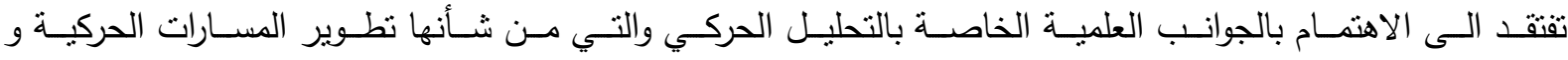

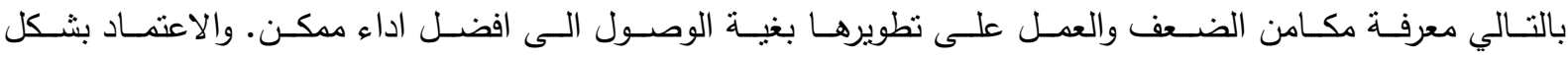

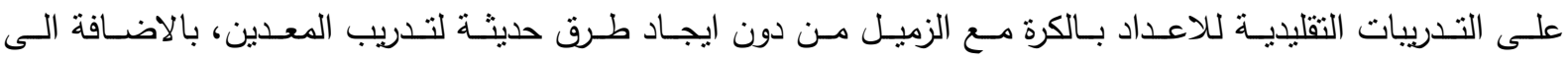

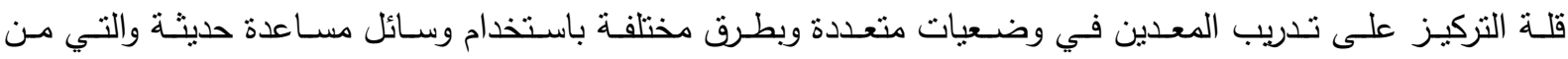

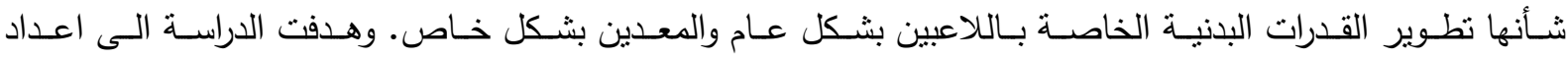

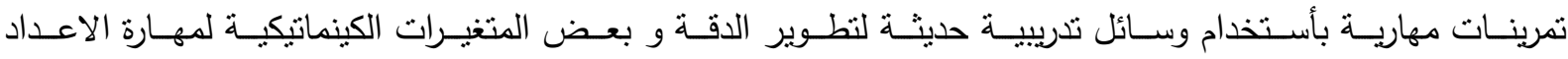
الواطئ والعالي من القفز . مهن.

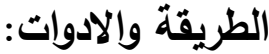

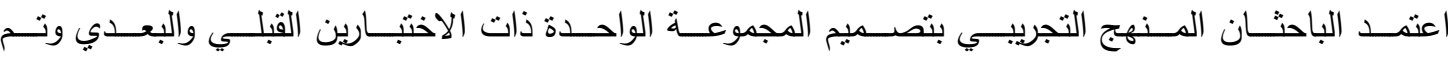

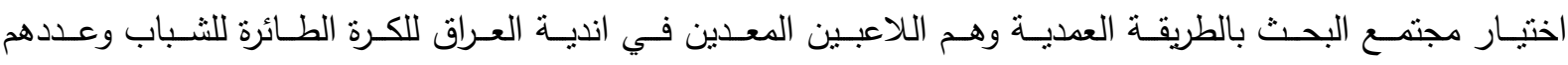

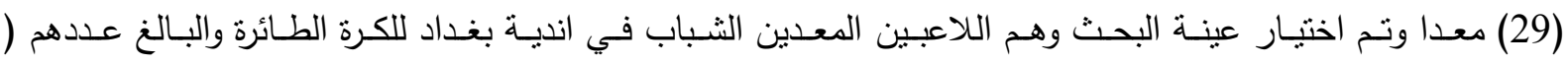

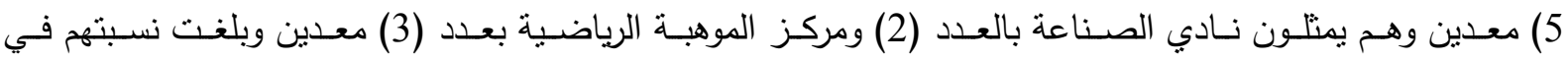

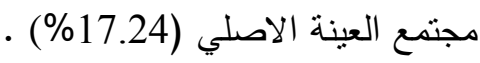
وقد هـدفت الدراسـة السى اجـراء اختبـار قبلـي للعينـة ثم التـدريب لمـدة شـهرين بمقدار (3) وحدات اسـبوعا

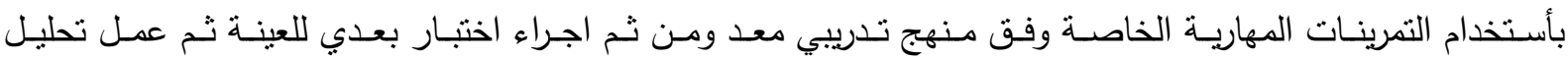

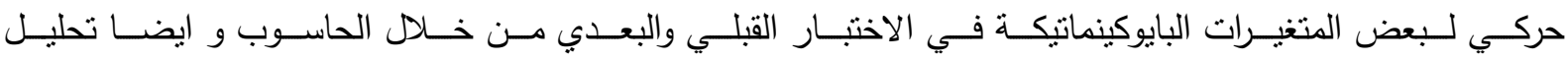

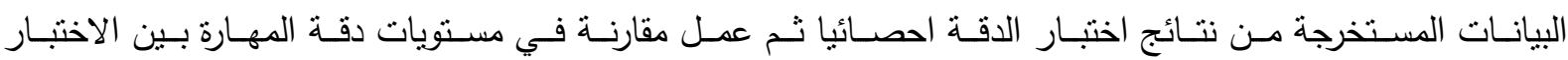
القبلي والبعدي.

اختبار الاعداد القريب من الثبكة. (محسن، 2002) الغرض من الاختبار : قياس دقة الاعداد القريب من الثبكة.

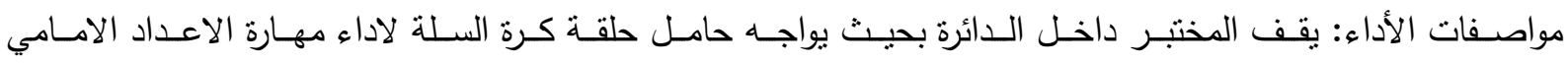

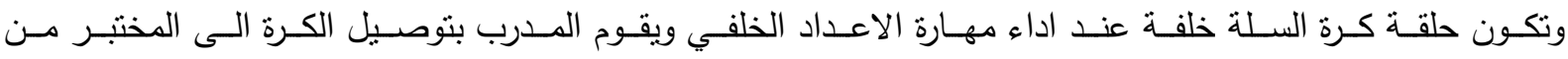
الموقع المخصص له كما مبين بالثكل (1) ليقوم المختبر بدوره باعداد الكرة الى حامل حلقة كرة السلة. الثروط: تعطى لكل لاعب (3) محاولات ويجب ان يتم الاعداد من داخل الدائرة.

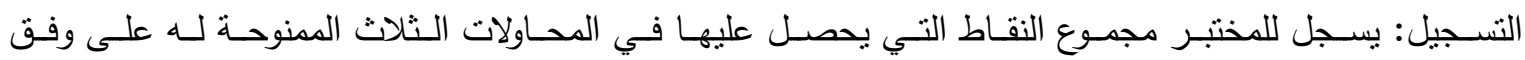

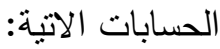

تعطى ثلاث درجات لكل محاولة تدخل فيها الكرة الحلقة من دون ملامستها 
• • تعطى درجتان لكل محاولة تدخل فيها الكرة الحلقة مع ملامستها

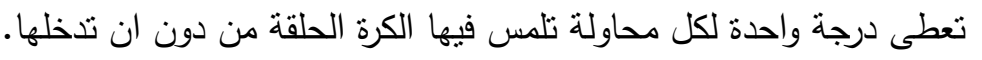
يعطى صفر ، في حالة أي اداء يخالف ما سبق ذكره.

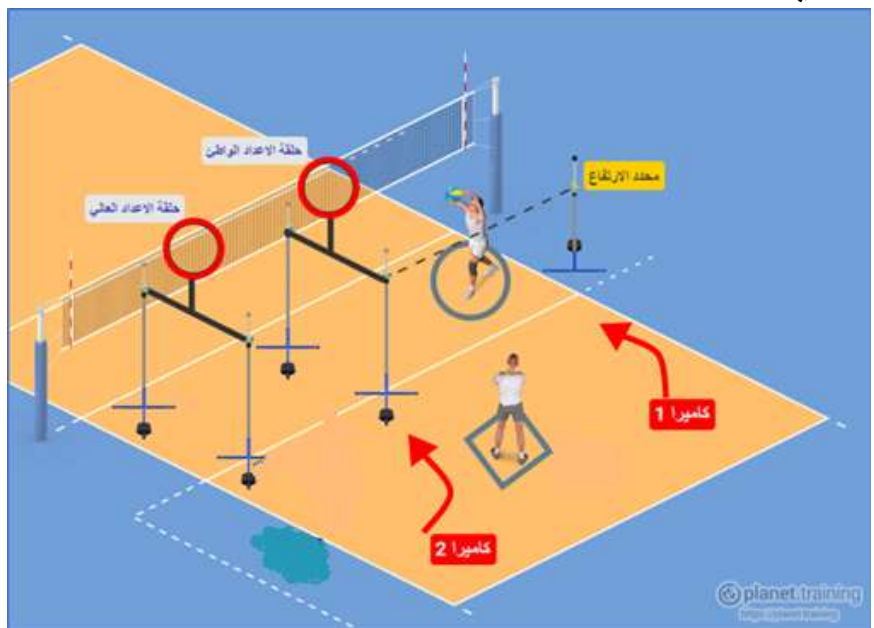

الثنكل رقم (1) مخطط يوضح اختبار دقة الاعداد الواطئ و العالي من القفز

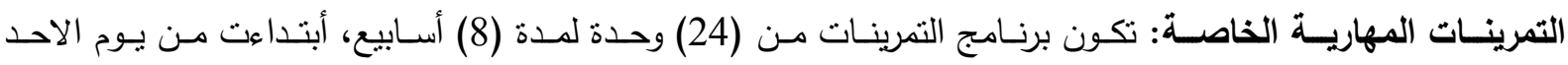

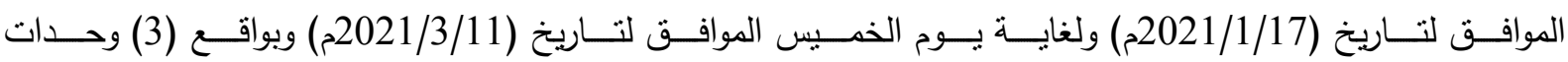

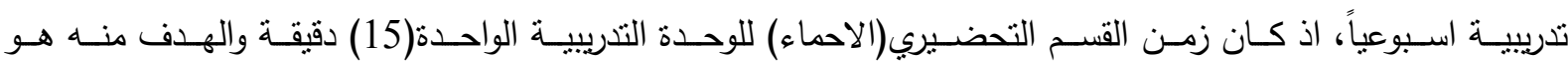

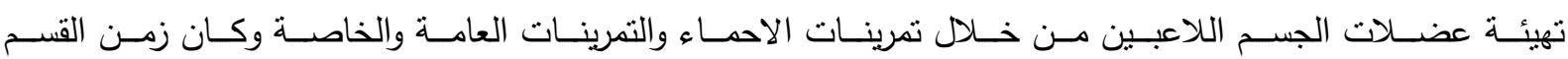

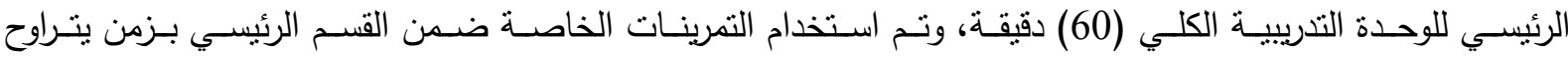

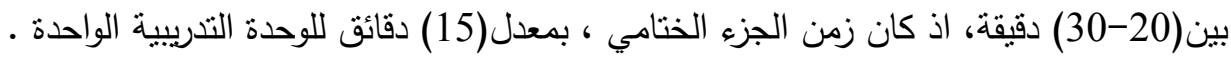

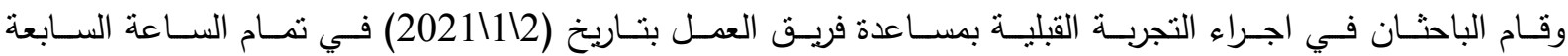
مساءا ، ثم بدأ بعدها بأجراء الوحدات التنريبية ـ وفي ادناه بعض الايضاحات حول منهرج التهات التمرينات الخاصة: تم اعطاء المنهج التدريبي للتمرينات الخاصة خلال فترة الاعداد الخاص من المنهاج التاه التدريبي.

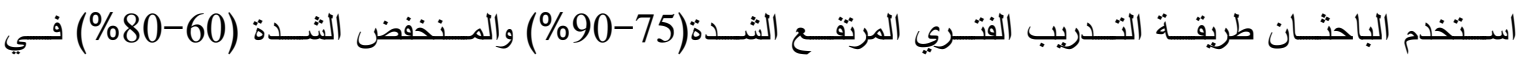

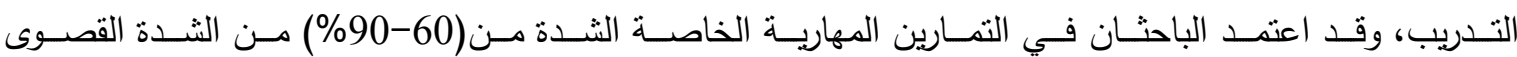

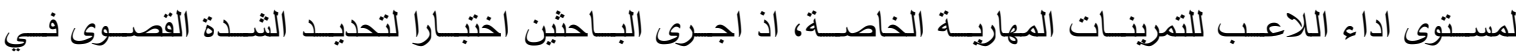

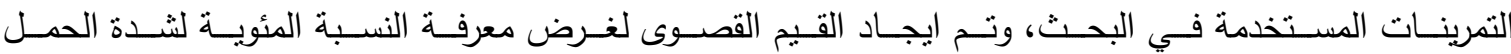
للتمرينات وتثبيتها في المنهج التنريبي للتمرينات الخاصة.

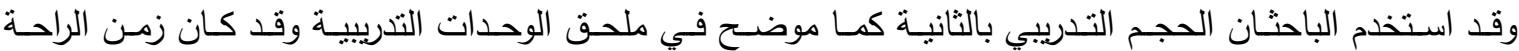

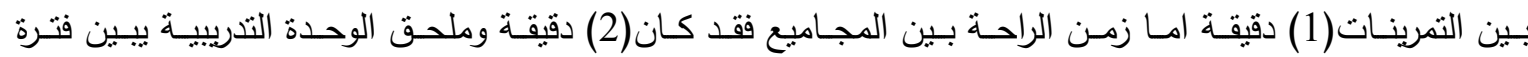
التمرينات في الوحدة التنريبية.

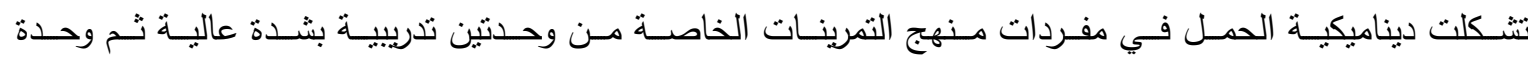
تحريب بشدة منوسطة أي نسبة(2-1).

أعتمد الباحثانان في تحديد فترات الراحة بين التمرينات أن نكون كافية لإستعادة الحالة الوظيفية الطبيعية.

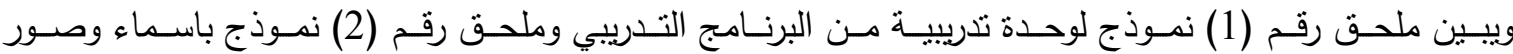
توضيحية للتمارين المستخدمة في البرنامج التدريبي 


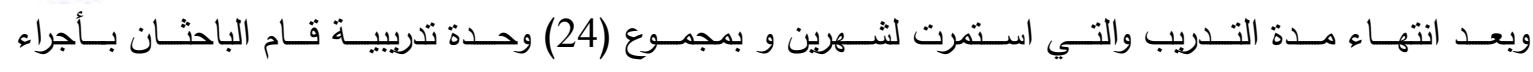

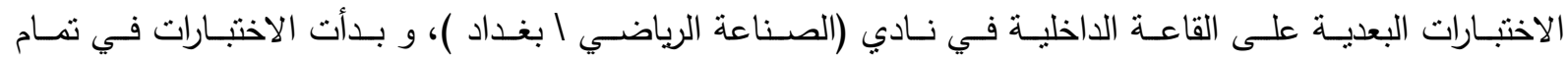
الساعة الخامسة مساءا وبمساعدة فريق العمل المساعد وفي نفس ظروف الاختبار القبلي .

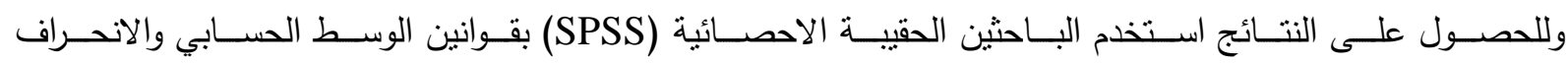
المعياري و اختبار (T TEST) للعينات المتتاظرة .

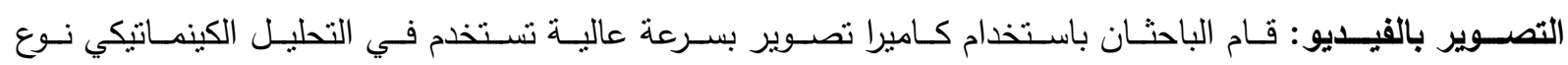
(Apple) ذات تـردد (120 صاث) بعدد (2) مـن اجل تصـوير اللاعب المعد اثتـاء اختبـار دقـة الاعداد الـواطئ

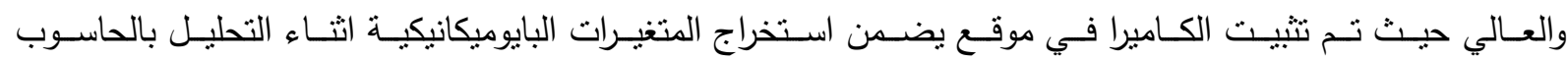
بأفضل صورة واستخدم الباحثان مقياس رسم بطول (1م) •

الجدول (1) يبين الأوساط الحسابية والانحرافات المعيارية واختبار الفروق ومستوى الدلالة للاختبارين القبلي والبعدي لمجموعة من المتغيرات لمهارة الاعداد الامامي الواطئ من القفز ولئز

\begin{tabular}{|c|c|c|c|c|c|c|c|c|}
\hline \multirow{2}{*}{ 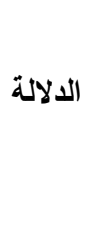 } & \multirow{2}{*}{ الديمة } & \multirow{2}{*}{$\begin{array}{c}\text { T } \\
\text { المحسوية }\end{array}$} & \multicolumn{2}{|c|}{ الاختبار البعدي } & \multicolumn{2}{|c|}{ الاختبار القبلي } & \multirow{2}{*}{ القياس } & \multirow{2}{*}{ المتغيرات } \\
\hline & & & $\varepsilon$ & س س & $\varepsilon$ & س س س & & \\
\hline معنوي * & .009 & 4.820 & .01342 & .1140 & .02168 & .1420 & 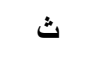 & زمن انطلاق الكرة \\
\hline معنوي * & .038 & 3.056 & .05874 & .8800 & .05805 & .7520 & 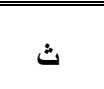 & زمن مس وترك الكرة \\
\hline معنوي * & .008 & 4.866 & 4.462 & 165.88 & 4.589 & 156.76 & داث & السرعة الزاوية للركبة \\
\hline معنوي * & .001 & 7.759 & 3.588 & 135.148 & 3.2185 & 131.338 & داث & اللحرعة الزاوية \\
\hline معنوي " & .005 & 5.706 & .79219 & 35.0380 & 1.26136 & 31.2640 & داث & السرعة الزاوية للرسغ \\
\hline معنوي * & .015 & 4.101 & 1.75699 & 23.4800 & 1.54986 & 27.4140 & ماث & لمفصل الورك العمودية \\
\hline معنوي" & .037 & 3.066 & .02702 & 5.8740 & .51737 & 5.1880 & ماث & سرعة انطلاق الكرة \\
\hline معنوي" & .000 & 14.333 & 15.20668 & 151.1600 & 14.60832 & 159.7600 & درجة & زاوية الركبة \\
\hline معنوي " & .042 & 2.959 & 6.03548 & 160.8200 & 7.45299 & 152.4200 & درجة & زاوية الكتف \\
\hline معنوي * & .015 & 4.075 & 7.03435 & 174.2080 & 9.69081 & 169.3280 & درجة & زاوية الورك \\
\hline
\end{tabular}

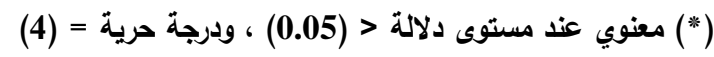


مجلة التربية الرياضية - المجلد (33) - العدد (3) - سنة 2021.

الجدول (2) يبين الأوساط الحسابية والانحرافات المعيارية واختبار الفروق ومستوى الدلالة للاختبارين القبلي والبعدي

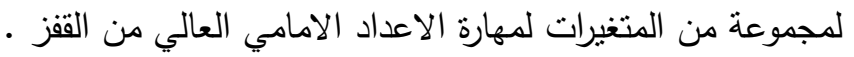

\begin{tabular}{|c|c|c|c|c|c|c|c|c|}
\hline \multirow{2}{*}{ الدلادة } & \multirow{2}{*}{ الديمة } & \multirow{2}{*}{ المحسوية } & \multicolumn{2}{|c|}{ الاختبار البعدي } & \multicolumn{2}{|c|}{ الاختبار القبلي } & \multirow{2}{*}{ وحدة } & \multirow{2}{*}{ المتغيرات } \\
\hline & & & $\varepsilon$ & س س & $\varepsilon$ & س س & & \\
\hline معنوي * & .035 & 3.138 & .01342 & .1160 & .00837 & .1320 & 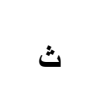 & زمن انطلاق \\
\hline معنوي * & .033 & 3.191 & .31540 & 1.0840 & .14526 & 1.4500 & 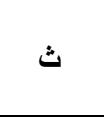 & زمن مس وترك \\
\hline معنوي * & .010 & 4.543 & 5.13907 & 235.1840 & 12.40783 & 261.8760 & داث & اللسرعة الزاوية \\
\hline مغنوي * & .035 & 3.131 & 56.87369 & 197.6260 & 57.87862 & 212.4260 & داث & للحوض النرعة الزاوية \\
\hline مغنوي * & .009 & 4.722 & 2.37995 & 35.3680 & 5.21107 & 28.8880 & داث & للالسرعة الزاوية \\
\hline معنوي * & .023 & 3.601 & 5.22731 & 30.1220 & 2.50725 & 24.7440 & ماث & لمفصل العورية \\
\hline مغنوي " & .017 & 3.517 & .48603 & 4.5833 & .62198 & 4.2917 & ماث & سرعة انطلاق \\
\hline معنوي * & .007 & 5.026 & 16.91070 & 162.5340 & 13.21682 & 144.0340 & درجة & زاوية الركبة \\
\hline مغنوي * & .013 & 4.265 & 7.89042 & 146.8840 & 4.71294 & 133.0720 & درجة & زاوية الكتف \\
\hline غنير & .055 & 2.679 & 12.78582 & 158.3200 & 18.44511 & 144.3200 & درجة & زاوية الورك \\
\hline
\end{tabular}

(4) (4) مغنوي عند مستوى دلالة > (0.05) ، ودرجة حرية (4)

الجدول (3) يبين الأوساط الحسابية والانحرافات المعيارية واختبار الفروق ومستوى الدلالة للاختبار دقة الاعداد الواطئ والعالي من القفز والثبات

\begin{tabular}{|c|c|c|c|c|c|c|c|c|}
\hline \multirow{2}{*}{ الدلالة } & \multirow{2}{*}{ قيمة الدلالة } & \multirow{2}{*}{ المحسوية } & \multicolumn{2}{|c|}{ الاختبار البعدي } & \multicolumn{2}{|c|}{ الاختبار القبلي } & \multirow{2}{*}{ القياس } & \multirow{2}{*}{ الاختبارات } \\
\hline & & & $\varepsilon$ & س س & $\varepsilon$ & س س & & \\
\hline معنوي * & .013 & 4.221 & 1.30384 & 6.2000 & 1.14018 & 3.4000 & د & دقه الاعداد العالي \\
\hline معنوي " & .000 & 4.675 & .72375 & 2.3333 & .45774 & 1.2667 & د & دقة الاعداد الواطئ \\
\hline
\end{tabular}

(") منوي عند مستوى دلالة > (0.05) ، ودرجة حرية = (4) ملفز 
فـي ضـوء البيانـات المسـتخرجة لافـراد عينـة البحـث للمتغيـرات البايوكينماتيكيـة التـي يوضـحها الجـدول (1) اظهـرت النتائج مـا يـأتي: فمـا يخص المتغيـر الخـاص بـزمن انطـلاق الكـرة فقد جائت النتائج معنويــة ولصــالح الاختبـار البعدي وهذا مـا يـدل على تطـور في النتائج مقارنـة بالاختبـار القبلي حيث اصبح اسـرع ويعزو الباحثنان السـبب الـى انخفـاض ارتقـاع الكـرة عـن مسـتوى الثـبكة وقـرب اللاعب الضــارب مـن اللاعـب المعـد في الاعـداد الـواطىء. أمـا فيمـا يخص زمسن مس وترك الكرة فـان الباحثنان يـرى ان نقصـان الزمن في هذا المتغير هو تطور

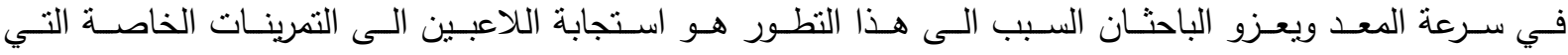
سـاعدتهم في تطوير القابليـة على مس و ترك الكرة باسـرع وقت ممكن وهـذا مـا يعطي للمعد (الغـرض مـن هـذا

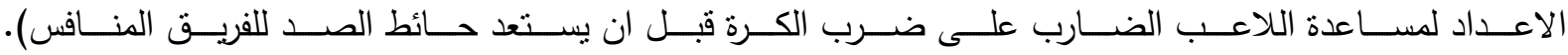
Hippdyte) الاختبـار البعـدي وهـذا يعنـي ان هنـاك زيـادة في السـرع والزيـادة تعكس النطـور الملحـوض للمعـدين والتـاثير الكبيـر

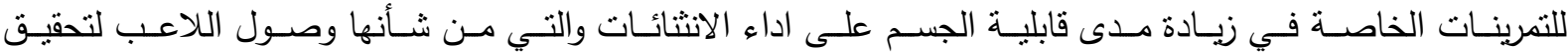
متطلبـات المهـارة ـ امــا السـرعة الزاويـة للرسـغ فالنتـائج اظهرت هنـاك تطـور ملــوض في هـا المتغيـر وهـذا يـدل

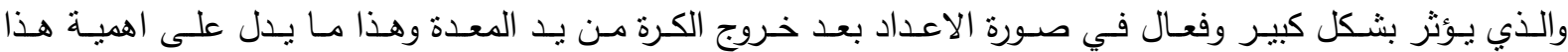
(Hippdyte, المتغير حيث ان (عند قيـام اللاعب المعد باعداد واطسى يجب عليه استخدام الرسـغ بشكل فعـال) (1989.امـا متغيـر السـرعة العموديـة لمفصـل الـورك فقد جائت النتـائج معنويـة لصـالح الاختبـار البعدي وبمعـدل اعلى مـن الثبـات كـون اداء مهارة الاعداد مـن القفز تتطلب نقل القوة مـن الارض الـى الاطـراف العليـا والقفز وهذا

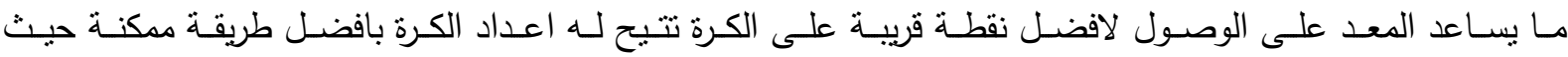

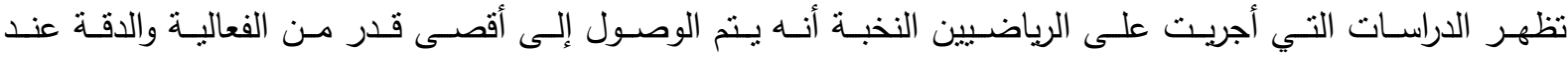

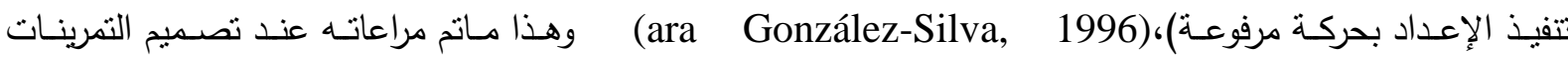

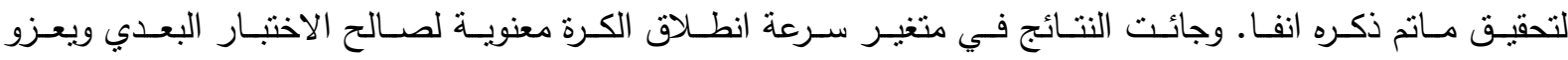

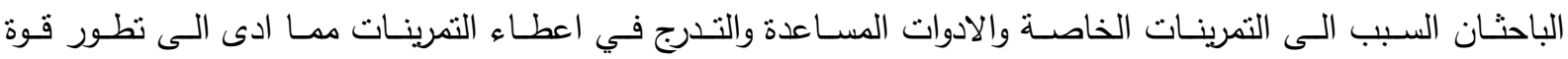

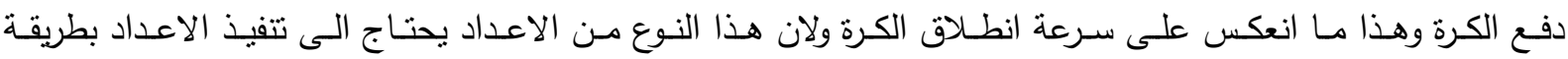

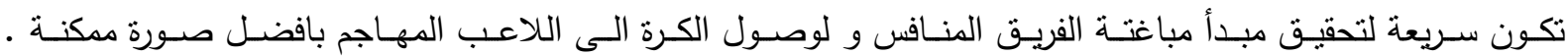

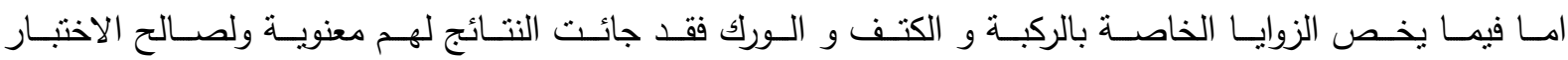
البعدي وهـذا مـا يـدل على تطـور القابليـات البدنيـة و تحسـن السـلوك الحركي للمعدين بغيـة الوصـول الـى متطلبـات الاداء الصحيح.

فــي ضـوء البيانـات المسـتخرجة لافـراد عينـة البحـث للمتغيـرات البايوكينمانيكيـة التـي يوضـحها الجـدول

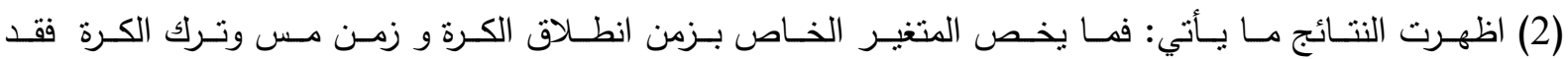

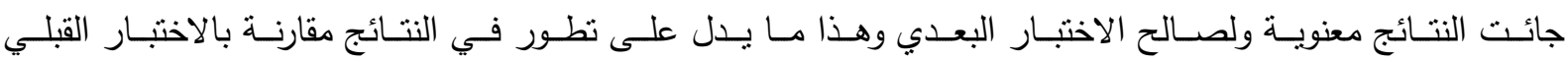

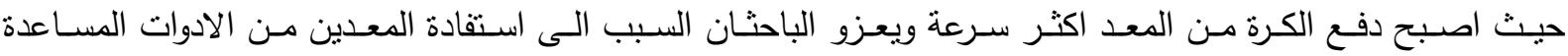

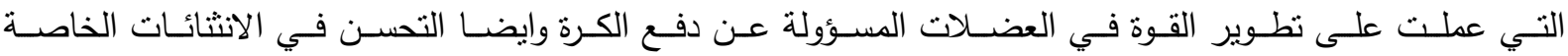

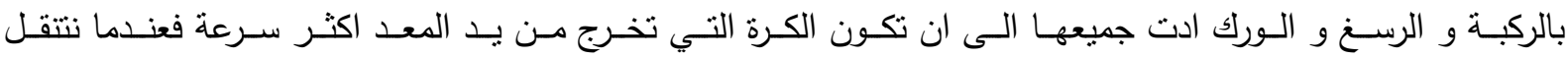

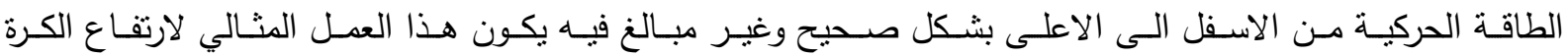

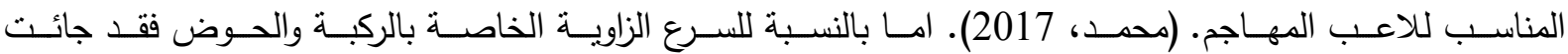
النتـائج معنويـة لصـالح الاختبـار البعـدي وهـذا يعنـي ان هنـاك اسـتفادة و تطـور نتيجـة اسـتخدام الادوات المســاعدة 


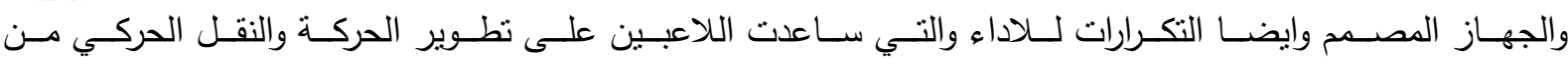

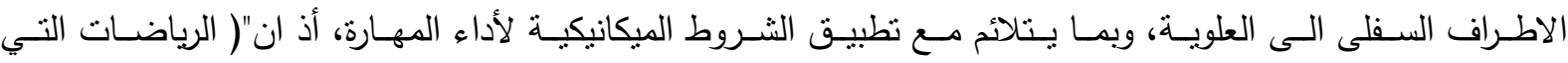

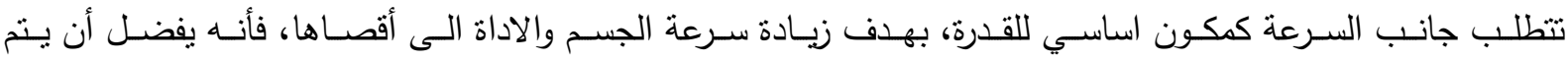

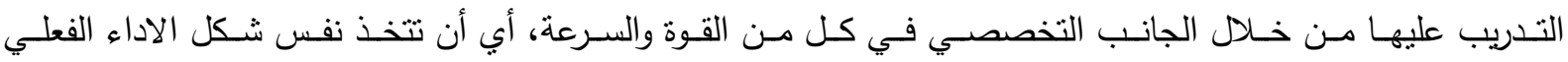

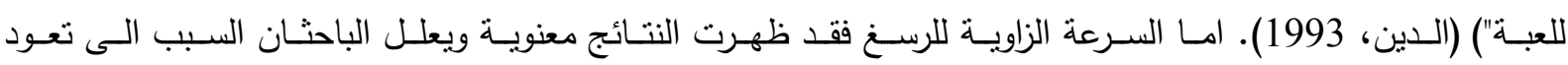

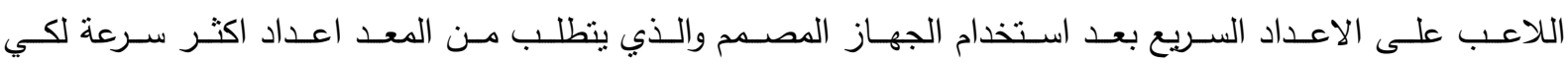

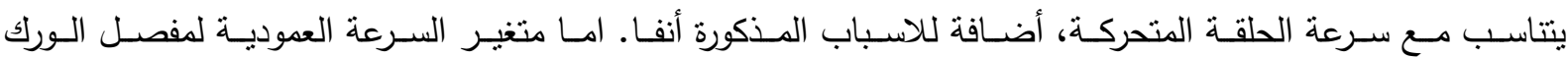

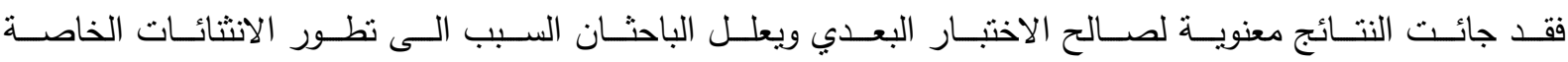

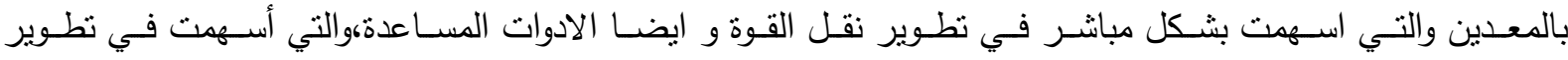

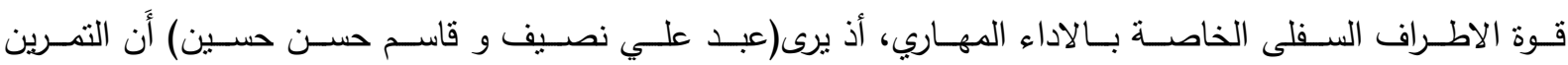

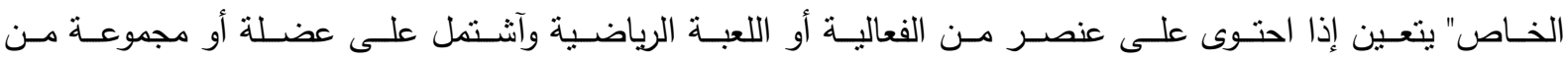

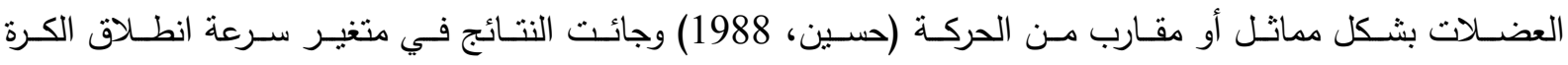

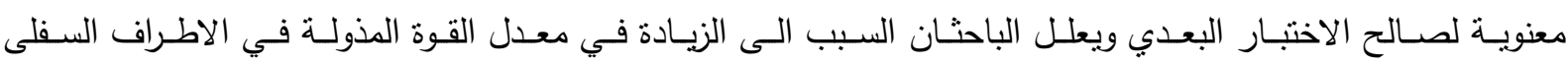

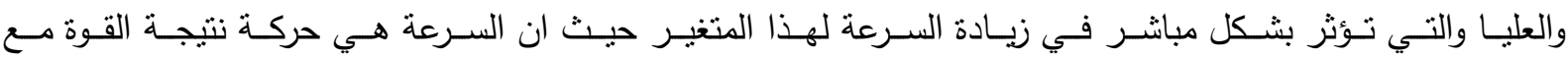

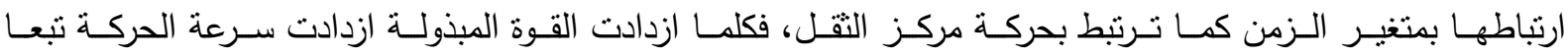

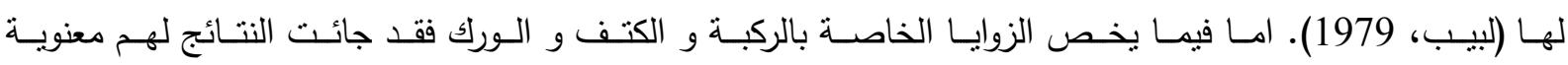

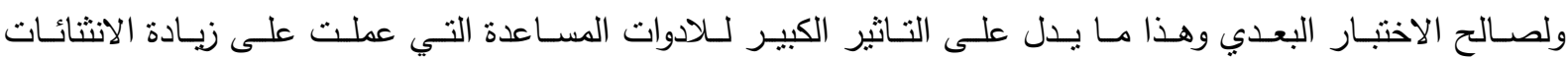

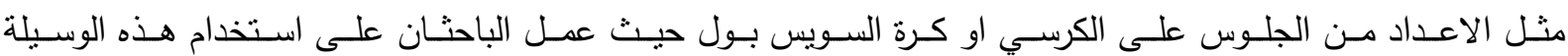

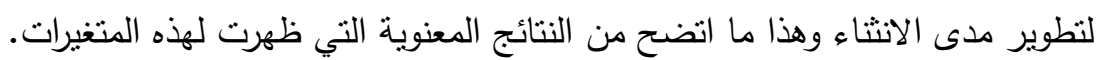

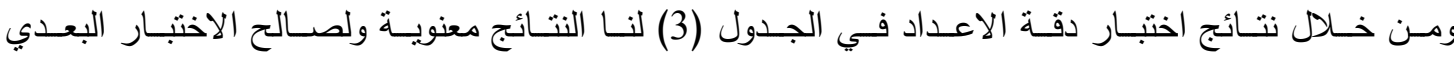

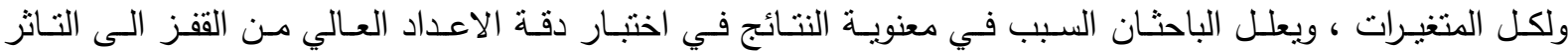

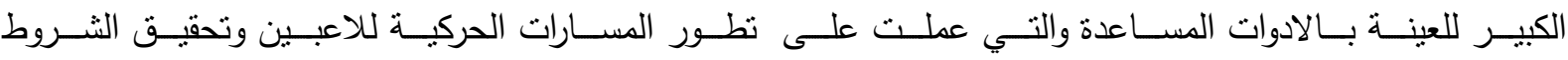

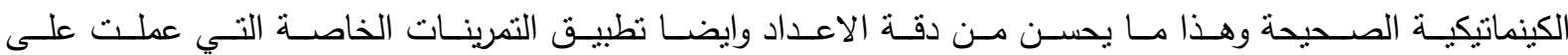

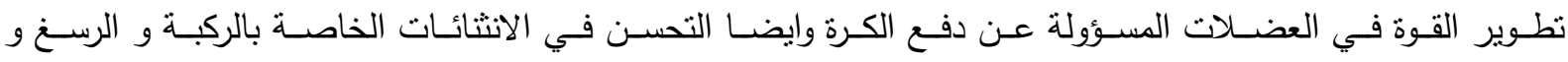

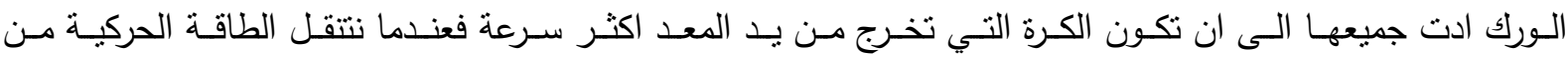

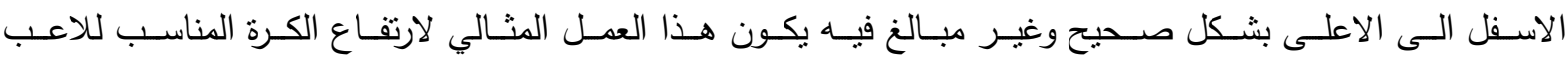

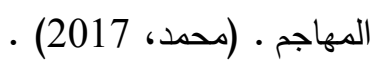

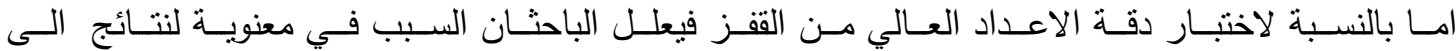

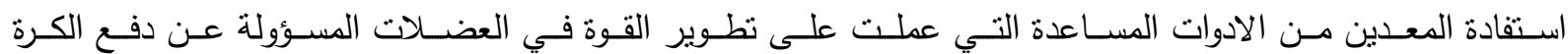

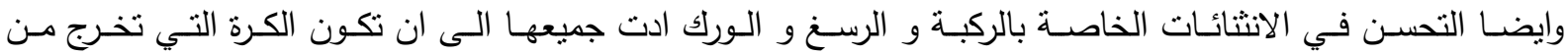

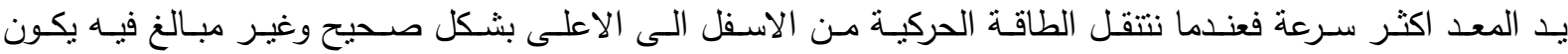

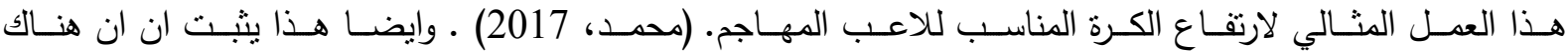

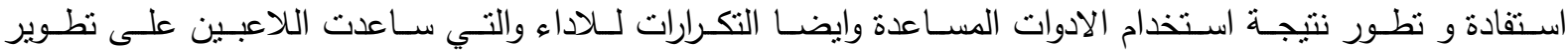

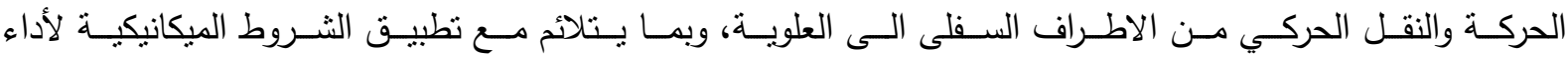

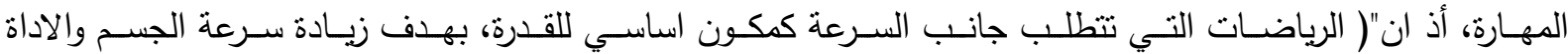




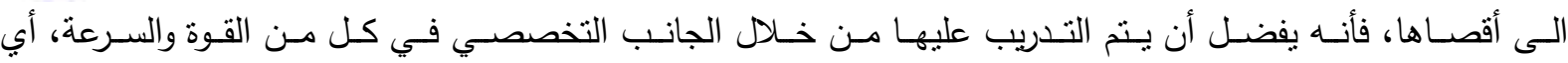

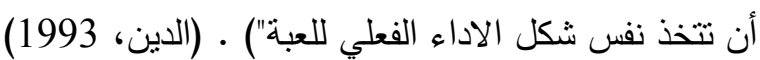

\section{المصادر}

حسـام حسـين دحـام : تـأثثر تصــيم تمرينـات خاصـة باسـتخدام جهـاز مقتـرح للمثيـر البصـري فـي سـرعة

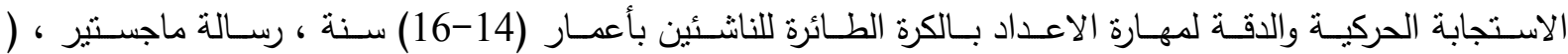

جامعة بغداد ، كلية التربية البدنية وعلوم الرياضة ، 2019)

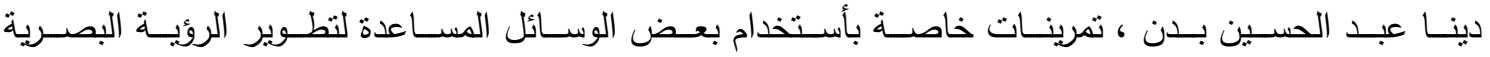

وتأثيرها في دقة أداء مهارة الضرب الساحق بالكرة الطائرة للثباب ،رسالة ماجستير ، 2015

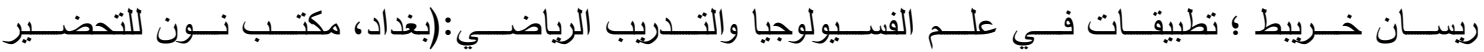
الطباعي، 1995) ص565) م

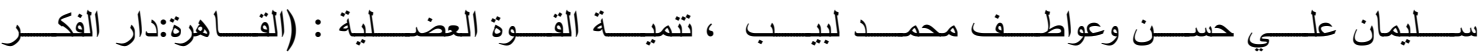

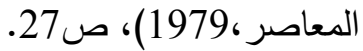

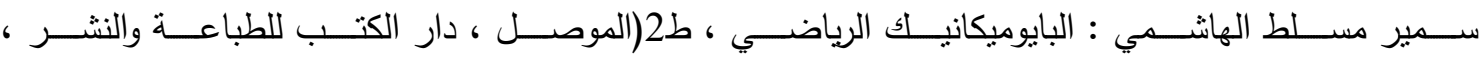

عبـــ علـي نصـيف، قاســ حسـن حسـين؛ مبــادئ علـم التـدريب الرياضـي: (مطبعـة التعليم العـالي، بغـداد،

عـلاء محسـن؛ دراســة مقارنـة فـي بعـض المتغيـرات البايوكينماتيكيـة لـبعض انـواع مهـارة الاعـداد وعلاقتهـا

بالدقة في لعبة الكرة الطائرة، رسالة ماجستير ، (جامعة بغداد، كلية التربية الرياضية، 2002)

قاســ حســ حسـين وايمـان شـاكر محمـود :الاسـس الميكانيكيـة للحركـات الرياضــية : (عـــان ، دار الفكـر

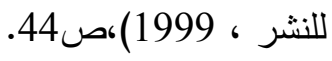

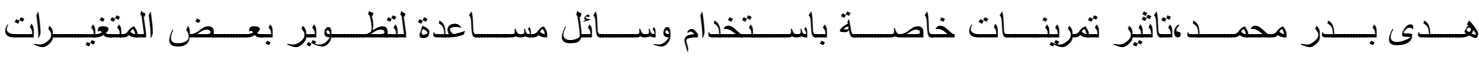

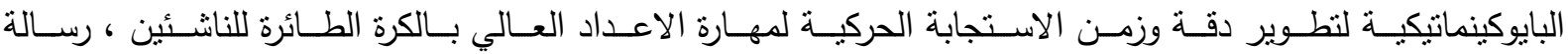
ماجستير ، جامعة بغداد .2017 .ص88. وجيه محجوب : علم الحركة ، بغداد ،بيت الحكمة ، 1985، ص الـ 33.

Analysis of Setting Efficacy in Young Male and Female Volleyball Players by Jara González-Silva1, Alberto Moreno Domínguez1, Carmen Fernández-Echeverría1, Fernando Claver Rabaz1, M. Perla Moreno Arroyo1 p 23 .

Brad Kilb and Keith Wasylik; Op. Cit., P.6-11. Brad and Keith Wasylik; Coaches Manual level1, 1st . ed: (Canada; Canadian Volleyball Association, 1986).

Claude Lapre and Keith wasylik; Op. Cit, P.6-5.

Liba , marie R. Effcts of activity in Larson, leonard a. and herrmann, Donald E. (eds). Encyclopedia of sport sciences and medicine, new York:

Mohr, D. $\mathrm{R}$.the contributions of physical activity to skill learning. Research quarterly ,1960.p.321.

Ralph Hippdyte; Setter training: (Volleytech, FIVB, No. 3+4, 1989) P.54.

the macmillan company, 1971.p.172. 


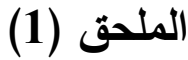

نموذج للتمرينات الخاصة

اداء مهارة الاعداد السريع من الوقوف باتجاه حلقة الدقة الاولى في مركز (3)

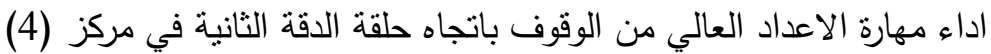

اداء مهارة الاعداد الوطئ من الققز باتجاه حلقة الاختبار المتحركة في مركز (3) من الملعب .

اداء مهارة الاعداد العالي من القفز باتجاه حلقة الدقة المتحركة للجهاز المصمم في مركز (4) ـ

اداء مهارة الاعداد العالي جلوسا على كرسي موضوع فوق منضدة باتجاه حلقة الدقة الثانية في مركز (3)

اداء مهارة الاعداد العالي جلوسا على كرسي موضوع فوق منضدة باتجاه حلقة الدقة الثانية في مركز (4)

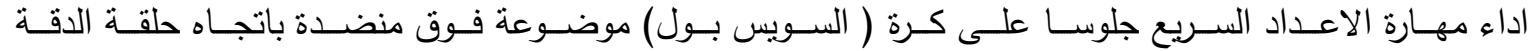

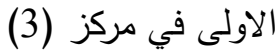

اداء مهـارة الاععداد العـالي جلوسـا على كـرة ( السـويس بـول) موضـوعة فوق منضـــة باتجـاه حلقـة الدقـة الثانيـة

في مركز (4) في (4)

تمرين مماثل للتمرين رقم (5) باتجاه حلقة الدقة المتحركة للجهاز المصمم في مركز (3)

تمرين ممانل لرقم (6) باتجاه حلقة الدقة المتحركة للجهاز الصمم في مركز (4) باهن

تمرين مماثل للتمرين رقم (7) باتجاه حلقة الدقة المتحركة للجهاز المصمم في مركز (4) لماهد

تمرين مماتل لرقم (8) باتجاه حلقة الدقة المتحركة للجهاز الصمم في مركز (3)

اداء مهارة الاعداد العالي من القفز باتجاه الحلقة الثانية للدقة في مركز (4) اداء مهارة الاعداد الواطئ

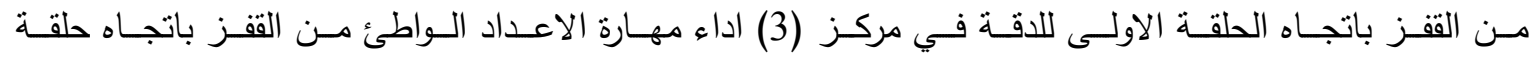

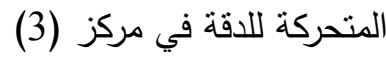

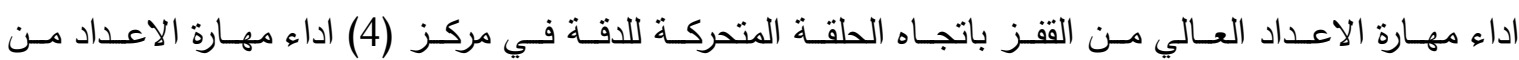
الثبات باتجاه الجهاز المصمح للمركزين (3) و (4) حسب حركة الجهاز المحددة من المدرب.

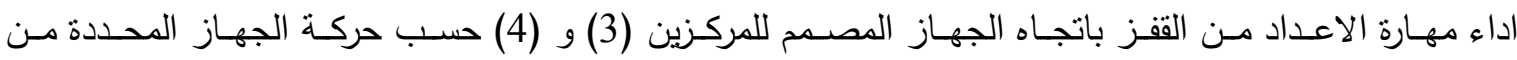


الهدف التدريبي: تطوير دقة مهارة الاعداد

زمن الوحدة: 90 دقيقة
الاسبوع: الاول

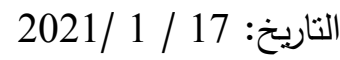

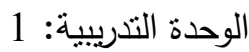

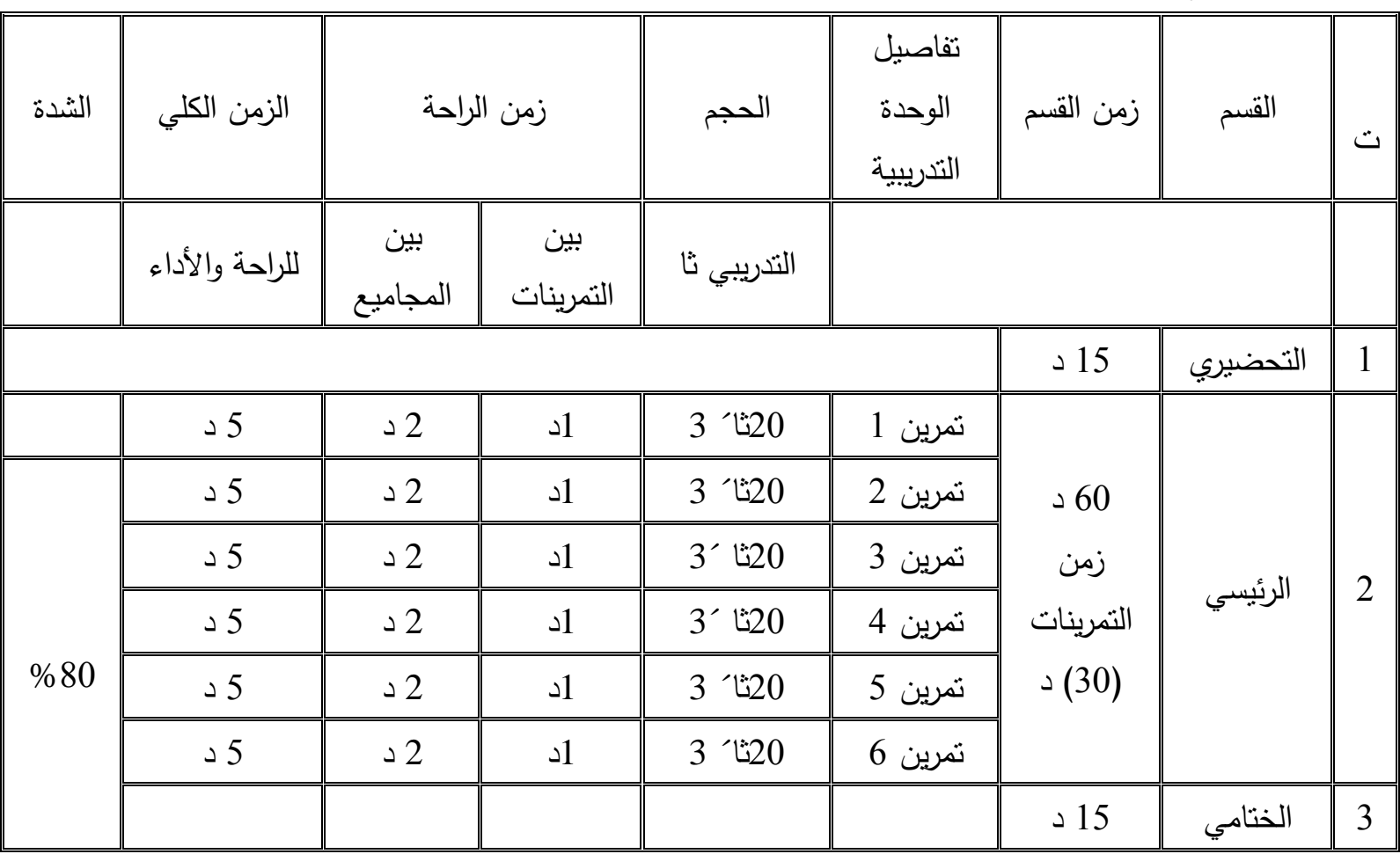

